on material from various tribes of the Indians of North America. Instructions are reduced to their simplest terms, and a brief introduction sets out the significance of the string-figure, and explains why it is of interest to science as an indication of the life and thought of the people among whom each type of game occurs. Mrs. Rishbeth has considerately supplied a suitable piece of string which is attached to the book for the use of the reader.

\section{Health of the Navy during I933}

THE health of the Navy during 1933 is detailed by the Medical Director-General, Surgeon ViceAdmiral R. W. B. Hall, in the Statistical Report of the Health of the Navy for the Year 1933 (London : H.M. Stationery Office. $2 s .6 d$. net). In a total force of 83,125 , the number of cases of disease and injury was 41,852 , a ratio of $503 \cdot 48$ per thousand, an increase of 40.53 in comparison with the five years' average and an increase of 31.80 in relation to 1932 . The increase appears to be mainly due to an increase in the incidence of influenza and tonsillitis. Malaria, venereal diseases, tuberculosis and injuries, all show a decrease. The total number invalided also shows a decrease. Details are given respecting cases of interest and the pathological tests and surgical technique employed.

The Natural History Museum and Broadcasts to Schools

THE trustees of the British Museum have arranged for special talks and exhibits at the Natural History Museum in connexion with the biology course being broadcast to schools on Wednesdays, from September 25 until December 11, from 2.30 to 2.50 p.m. Within the limits of the accommodation, schools may attend at the Museum and listen to the broadcast talk in the board room, and immediately afterwards visit the appropriate specimens in the galleries under the guidance of the museum guide lecturer. For the benefit of schools which prefer to receive the broadcasts in their own classrooms, a special tour of the specimens by the guide lecturer will be available every Thursday at 2.30 p.m. For schools which may find it more convenient to attend at the museum only once or twice a term, more extensive tours may be arranged if particulars of what is required be addressed to the director. Arrangements also may be made with the director for schools unable to attend on Thursday afternoon to have the same lecture tour at some other time.

\section{Announcements}

THE ninety-fourth session of the School of the Pharmaceutical Society of Great Britain will begin on October 2, when Sir Frederick Gowland Hopkins will deliver the inaugural sessional address, at $\mathbf{3}$ p.m.

Prof. Albert Szent-Györgyi, who discovered vitamin $\mathrm{C}$ in capsicum, has succeeded Prof. Szeuky as director of the First Chemical Institute and professor of organic chemistry at Szeged.
The twenty-fourth Congress of the Italian Society for the Advancement of Science will be held in Palermo on Oetober 12-18 under the presidency of His Excellency the Honourable Di Marzio, rector of the University.

The German General Medical Congress for Psychotherapy will be held at Breslau on October 3-6, when the subject for discussion will be psychical treatment in relation to psychiatry, internal medicine and education. Further information can be obtained from Dr. Hausdörfer, Psychiatrische Klinik, Breslau.

THE Fishery Institute of the University of Königs. berg, directed by Prof. Willen, has organised a vacation course from October 9 until October 16 at the sea fishery station at Neukuhren, Samland, consisting of lectures, practical work and excursions, to illustrate the hydrography and biology of the Baltic. Further information can be obtained from Fischerei Institut, Universität, Königsberg.

Particulars of lectures, courses and classes arranged by the Warburg Institute and dealing with the survival of classical elements in European history of religion, social life, fine arts, science and literature have recently been issued. All lectures, courses and classes are open to the public, and admission is free. Further information can be obtained from the Secretary, Warburg Institute, 3 Thames House, Millbank, London, S.W.1.

The sixth Turkish Medical Congress will be held at Angora at the end of October under the patronage of the President of the Turkish Republic and the presidency of General Ismet Inöniü, the president of Council and Prof. Refik Saydan, the Minister of Health and Social Assistance. The subjects for discussion will be rheumatism and alcoholism and drug addiction in Turkey. An exhibition of pharmaceutical products and medical instruments will be held during the Congress. Further information can be obtained from the general secretary, Prof. Fahrettin Kerim, 15 Boulevard D'Angora, Stamboul, Turkey.

Applications are invited for the following appoint. ments, on or before the dates mentioned :

A temporary demonstrator in botany in the University of Leeds-The Registrar (Sept. 30).

A lecturer in engineering in the Plymouth and Devonport Technical College-The Secretary for Education, Coburg Street, Plymouth (Oct. 5).

An assistant pomologist at the John Innes Horticultural Institution, 21 Mostyn Road, S.W.19-The Secretary (Oct. 7).

A chemical pathologist in the Department of Clinical Investigations and Research in the Manchester Royal Infirmary--The Director (Oct. 11).

A curator of the Zanzibar Museum-The Director of Recruitment (Colonial Service), 2 Richmond Terrace, Whitehall, London, S.W.1 (Oct. 15). 